Список литературы:

1. Центральный государственный архив Самарской области (ЦГАСО). Ф-4253. Оп. 1. Д. 1.

2. Гс. Преступная Самара. Итоги Самгуброзыска за первое полугодие 1923 г. // Коммуна. 1923. 26 июня.

3. ЦГАСО. Ф-98. Оп. 1. Д. 835.

4. ЦГАСО. Ф-81. Оп. 1. Д. 630.

5. Н.Д. По базарам Самарской губернии // Коммуна 1925. 17 апреля.

6. Н.Д. По базарам Самарской губернии // Коммуна 1925. 6 мая.

7. Итоги десятилетия советской власти в цифрах. 1917-1927. М.: Центр. стат. упр. СССР, 1927. 520 с.
8. ЦГАСО. Ф-166. Оп. 1. Д. 247.

9. ЦГАСО. Ф-98. Оп. 1. Д. 995.

10. ЦГАСО. Ф-857. Оп. 5. Д. 125.

11. ЦГАСО. Ф-166. Оп. 1. Д. 155.

12. ЦГАСО. Ф-98. Оп. 1. Д. 996.

13. ЦГАСО. Ф-98. Оп. 1. Д. 688.

14. ЦГАСО. Ф-857. Оп. 6. Д. 1.

15. ЦГАСО. Ф-98. Оп. 1. Д. 810.

16. ЦГАСО. Ф-281. Оп. 1. Д. 140.

17. Разуваев К. Конокрадство в Самарской губернии // Коммуна. 1925. 19 мая.

18. ЦГАСО. Ф-98. Оп. 1. Д. 993.

19. ЦГАСО. Ф-81. ОП. 1. Д. 69.

\title{
HORSE STEALING IN THE SAMARA PROVINCE \\ IN 1923-1925
}

(C) 2018

Gizatulin Shamil Takhirovich, candidate of historical sciences

The Main Directorate of the Ministry of Internal Affairs of the Russian Federation in the Samara Region (Samara, Russian Federation)

Abstract. This paper considers the problem of horse stealing in the Samara province in 1923-1925. The author conducted a study of causes and dynamics of horse thefts in the region, as well as of measures of the law enforcement agencies with a criminal activity. The paper shows the factors that contributed along with the generally unfavorable socio-economic conditions of the 1920s years to the growth of this type of crime in the region. On the basis of statistical indicators of militia and criminal investigation the author has studied methods of horse thefts in the province, the reasons for the growth of this type of crime in 1923 and the decline by the end of 1925. The paper considers problems of professional horse stealing and ethnic crime (criminal activity of representatives of the Turkic peoples). The author has revealed seasonal and spatial characteristics of the prevalence of cattle theft and established «centers» of horse theft in the province (Samara, Samara and Buguruslan Districts), as well as analyzed efficiency of militia activity and criminal investigation department of Samara province in the fight against this crime. The paper also contains the drawbacks in the organization of activities of local authorities, law enforcement and the court, as well as measures taken by the provincial authorities for the suppression of horse stealing in the period.

Keywords: horse stealing; theft of livestock; crime factors; crop failures; law enforcement; police; criminal investigation department; village councils; professional crime; criminal statistics; dynamics of crime; seasonality of crime; territorial prevalence; Samara province; counties; Samara.

\section{«...Я УНЕС С ЮБИЛЕЯ АКАДЕМИИ НЕУГАСИМУЮ ИСКРУ ЛЮБВИ К НАУКЕ...» (ИЗ ВОСПОМИНАНИЙ П.В. ИВАНОВА - ЮНОГО УЧАСТНИКА 200-ЛЕТНЕГО ЮБИЛЕЯ РОССИЙСКОЙ АКАДЕМИИ НАУК)}

Бровина Александра Александровна, кандидат исторических наук, заведующий отделом гуманитарных междисциплинарных исследований

Егорова Светлана Львовна, кандидат исторических наук, старший научный сотрудник отдела гуманитарных междисциплинарных исследований Коми научный иентр УрО РАН (г. Сыктывкар, Российская Федерация)

Аннотащия. Данная статья посвящена одной из знаковых страниц в истории академической науки - 200летнему юбилею Академии наук СССР. Широкая программа «праздника науки» в международном масштабе, с приглашением иностранных ученых, указала на научное и политическое значение события, как для поднятия престижа Академии наук, так и для демонстрации международному сообществу лояльности научной элиты к новой власти. Исследователи неоднократно обращались к анализу этого мероприятия и подчеркивали его значение. Однако в преддверии очередного юбилея небезынтересно показать это событие с неофициальной позиции, привлекая источники личного происхождения. Основное внимание в статье уделено неопубликованным воспоминаниям Павла Владимировича Иванова (1906-1990 гг.), ученого-педагога, доктора педагогических наук, профессора, заслуженного учителя Карельской АССР. В 1925 г. он, юный краевед из г. Солигалича Костромской губернии, стал участником юбилейных академических торжеств. Впечатления, вынесенные от этого события, предопределило его дальнейшую судьбу и выбор профессии. П.В. Иванов, пройдя путь от ученика сельской школы, увлеченного краеведением, до школьного учителя, а затем и профессора университета, закладывал в своих студентах - будущих учителях - мысль о необходимости воспитывать у учащихся интерес, любовь и стремление к юннатской, краеведческой, научно-изыскательской работе. 
Ключевые слова: история Российской академии наук; юбилейные торжества; коллективная память; неопубликованные воспоминания; ученый-педагог; профессор Павел Владимирович Иванов; краеведческая, научно-изыскательская работа; воспитание учащейся молодежи; г. Солигалич Костромской губернии; Национальный архив Республики Карелия.

В последние десятилетия в гуманитарной науке активно обсуждается вопрос о соотношении истории и коллективной памяти. Эти, казалось бы, разные инструменты работы с прошлым в реальности часто становятся взаимодополняющими и сотрудничающими практиками. Проблема их соотношения актуальна для той категории профессиональных историков, которые взялись за решение новых задач - изучение формирования и динамики коллективной памяти, ее анализ, отслеживание манипуляции ею со стороны тех или иных социальных групп. На этом фоне закономерен и вполне оправдан пристальный интерес к личным свидетельствам о прошлом: дневникам, воспоминаниям, письмам.

Дневниковые записи, заметки, письма имеют исключительное разнообразие по форме и содержанию, затрагивают корневые, микроскопические формы бытия и содержат множество сведений по истории повседневности. Они позволяют реконструировать конкретное событие с точки зрения его участников. Разносторонний характер этих исторических источников позволяет в равной мере рассматривать события экономической, политической, социально-культурной истории, пропущенные через личное восприятие их авторов.

Обратим внимание на ту часть названных источников, которая посвящена истории Российской академии наук: отдельным исследователям, научному сообществу в целом, биографии РАН как института, вписанного в историю России. Речь идет об архивах ученых - богатейшем корпусе источников коллективной памяти научного сообщества. Эти документальные свидетельства особенно интересны в свете предстоящего 300-летнего юбилея Российской академии наук.

Создание Академии наук в России было ключевым элементом обновления страны, задуманного Петром Великим. К этому шагу подталкивала потребность промышленного роста страны, укрепления ее внешнеполитического статуса. Россия, по мысли императора, должна была влиться в общеевропейский процесс культурного развития.

Проект положения об учреждении Академии наук и художеств, составленный по указанию Петра I лейб-медиком, заведующим Кунсткамерой Л.Л. Блюментростом, был рассмотрен на заседании Сената 22 января (2 февраля) 1724 г. Академия, официальное открытие которой состоялось в 1725 г. после смерти императора, взяла на себя функции научного исследования и образования.

Научно-образовательная деятельность Академии позволила ей вскоре занять почетное место среди крупнейших научных учреждений Европы. К концу XIX в. Россия стала вторым по значимости после Германии научным центром мира.

Судьба Академии в переломную революционную эпоху и последовавший за ней советский период во многом зависела от политики новой власти и от поступков отдельных представителей научного сообщества.
2 декабря 1917 г. на заседании Общего Собрания Российской Академии наук (РАН) ее непременный секретарь, академик С.Ф. Ольденбург обратился к немногим, еще остававшимся в революционном Петрограде академикам с вопросом о предстоящем 200летнем юбилее. Тогда еще никто не знал, какую череду трагических событий пройдет Академия до своего юбилея.

С первых дней революции было понятно, что российским ученым «старой школы» не удастся остаться в стороне от происходящего, придерживаясь принципа «политической нейтральности». В этих условиях руководству Академии - первому избранному президенту РАН академику А.П. Карпинскому и секретарю С.Ф. Ольденбургу - приходилось искать пути защиты академического сообщества, демонстрируя пользу науки и просвещения для нового режима. Весной 1918 г. А.П. Карпинский заверил наркома просвещения А.В. Луначарского, что Академия наук, следуя традициям служения государству, будет помогать развитию производительных сил для общенациональных нужд. Ученым был предложен своего рода «новый академический курс», которого пришлось придерживаться [1]. В ответ Академия стала получать средства для своей работы и значительные преференции от власти.

Между тем первые советские годы привели к первым человеческим потерям. С 1917 по 1922 гг. Академия наук лишилась почти половины состава своих академиков: из 46 числившихся на 25 октября 1917 г. действительных членов к 1922-му 13 скончались, а семь оказались в вынужденной эмиграции и уже не вернулись в Россию. Однако к 1925 г., пережив голод и бытовые невзгоды («уплотнения», трудовые повинности) периода Гражданской войны, Академии наук удалось не только полностью восстановить персональный состав, но и существенно расширить свою деятельность, укрепить систему научно-исследовательских учреждений.

Свою роль в поднятии престижа Академии призван был сыграть академический юбилей 1925 г. Это событие имело и политическое значение как демонстрация международному сообществу лояльности научной элиты к новой власти. На это указывает содержание особой записки вице-президента РАН, академика-математика В.А. Стеклова, направленной в Особый временный комитет науки при СНК РСФСР, с предложением одобрить широкую программу празднования юбилея АН в международном масштабе с приглашением иностранных ученых, указав на научное и политическое значение события и на возможность сделать его национальным праздником. Предложение академика пришлось как нельзя кстати, нашло полное понимание у новой власти, только начинавшей преодолевать международную изоляцию Советской России. Созданную специальную Комиссию СНК СССР по организации празднования 200летнего юбилея РАН возглавил сам председатель СНК СССР А.И. Рыков [2, с. 28-30].

До этого момента Академия наук отмечала свой юбилей трижды: в 1776, 1826 и 1876 гг. В подготовке 
к юбилейной дате закладывалась традиция изучения истории АН (юбилейные речи об этапах развития академической науки, издание сборников документов и материалов, подготовка биографий выдающихся деятелей). Однако планомерное изучение истории Академии наук началось только в советский период. При этом академические юбилеи во многом стимулировали эту работу [3, с. 660]. Так что к политической значимости академического юбилея присоединялся и научный смысл события - повод оценить пройденный отечественной наукой путь и наметить новые задачи.

С начала 1925 г. Политбюро ЦК РКП (б) неоднократно рассматривало различные вопросы проведения академического юбилея, очередность постановки которых весьма точно демонстрирует приоритеты научной политики советского партийного руководства.

Впервые на заседании Политбюро заговорили о грядущем юбилее 25 февраля 1925 г., когда по докладу А.И. Рыкова было принято решение о желательности приезда иностранных ученых на торжества. Постановление СНК СССР «О праздновании 200-летнего юбилея Российской Академии наук 1 сентября 1925 г.» было принято лишь 25 июля 1925 г. В этом постановлении отмечалось, в частности: «Считать празднование 200-летнего юбилея Академии общесоюзным празднеством...» [4, ст. 363]. При разработке плана юбилейных мероприятий было внесено предложение о проведении демонстрации на Красной площади, но на заседании Политбюро ЦК 25 августа 1925 г. устройство демонстрации признали нежелательным и предложение отклонили.

Торжественное заседание в честь юбилея Академии проходило 6 сентября в зале Ленинградской филармонии. С приветствием от ЦИКа СССР и СНК СССР выступил М.И. Калинин. Особый интерес вызвало выступление А.В. Луначарского, озвучившего курс на включение академической науки в решение народнохозяйственных задач страны. С.Ф. Ольденбург в своей речи подвел основные итоги юбилея.

Торжество сопровождалось грандиозным банкетом на 800 человек в Мраморном зале Русского музея. Участники юбилейных торжеств познакомились с выставкой академических изданий и архивных документов за 200 лет, подготовленной Библиотекой АН и Архивом АН СССР. На приеме, устроенном Ленсоветом во дворце им. Урицкого (Таврический дворец), с речью по поводу юбилея выступил Г.Е. Зиновьев. 11 сентября торжества были продолжены в Москве в Большом зале Московской консерватории, где с речами к собравшимся обратились П.Г. Смидович и Л.Б. Красин. Праздничные мероприятия охватили около 1000 гостей и делегатов из различных советских учреждений, около 130 иностранных ученых из 24 стран (Англии, Франции, США, Италии, Германии, Австрии, Испании, Венгрии, Швеции, Дании, Норвегии, Бельгии, Голландии, Турции, Японии, Китая, Индии и Тибета). Всего было получено более 2 тысяч приветствий и адресов. Юбилей стал первой крупной международной встречей ученых после Первой мировой войны. Иностранные делегаты ознакомились с научной, культурной и общественной жизнью СССР, убедились в необходимости сближения с советской наукой. Всех поразил размах сети научных учреждений Российской академии наук [5, с. 43-44].

Участниками юбилея, что показательно для советского времени, оказались не только ученые и политики, но и представители российской провинции, начинающие краеведы.

Среди них - выходец из крестьянской семьи, юный краевед из Костромской губернии Павел Иванов. На юбилее Академии он представлял краеведов г. Солигалича. Событие 1925 г. оставило неизгладимый след в душе юноши, предопределив выбор профессии и его дальнейшую судьбу.

Воспоминания П.В. Иванова о грандиозном празднике науки были записаны им много позднее: в сентябре 1967 г. он составил «Воспоминания заслуженного работника науки и культуры Карельской АССР П.В. Иванова об участии в 200-летнем юбилее АН СССР» (машинопись, объем 6 листов), а в апреле 1974 г. - «Как я был участником 200-летнего юбилея Академии наук» (машинопись, объем 6 листов) [6].

Но прежде чем мы обратимся к этим записям, скажем несколько слов об авторе, Павле Владимировиче Иванове (1906-1990 гг.), ученом-педагоге, докторе педагогических наук, профессоре, заслуженном учителе Карельской АССР.

Еще в школьные годы (в 1917 г. окончил начальную школу, в 1926 г. школу 2-й ступени) он увлекся краеведением, в 1924 г. возглавил работу кружков юных натуралистов и стал участником 1-го Костромского губернского съезда юных натуралистов и краеведов.

В 1926 г. началась его педагогическая деятельность - преподавание географии и биологии в школах и училищах г. Солигалича. В 1931 г. Павел Иванов окончил Коммунистический университет в г. Иваново и Ленинградский государственный педагогический институт им. Н.К. Крупской (заочно). В течение 20 лет работал учителем, вел активную краеведческую и общественную работу в г. Солигаличе: был членом краеведческого общества, инициатором создания музея и участником районных экспедиций, написал ряд работ о своем крае.

В этот период времени П.В. Иванов поддерживал связи с известными деятелями науки К.Э. Циолковским, Н.И. Вавиловым, Т.Д. Лысенко, крупными учеными-педагогами проф. С.В. Ивановым, Б.П. Есиповым, Б.Г. Иоганзеном, М.Н. Скаткиным, Н.К. Гончаровым. В 1929 г. в Московском доме учителя встречался с Н.К. Крупской, слушал выступления М.И. Калинина, А.В. Луначарского, был на приемах академиков Н.И. Вавилова, А.Е. Ферсмана.

В годы Великой Отечественной войны П.В. Иванов, секретарь партийной организации педагогического училища и депутат горсовета, занимался делами эвакуированных в г. Солигалич. После окончания войны по указанию ЦК ВКП (б) был направлен на работу в Карелию, где принял участие в восстановлении института усовершенствования учителей (в 1945-1947 гг. был его директором). В 1947-1950 гг. исполнял обязанности заместителя министра просвещения республики. С 1950 г. работал в Петрозаводском университете (проректор по научной работе, декан историко-филологического факультета, в течение 30 лет заведовал кафедрой педагогики). Наг- 
Бровина А.А., Егорова С.Л.

«...Я унес с юбилея Академии неугасимую искру любви к науке...»..

07.00.00 - исторические науки и археология

ражден орденом «Знак Почета», медалями и Почетными грамотами [7, с. 361-362].

Личный фонд П.В. Иванова в Национальном архиве Республики Карелия содержит биографические материалы (справки, воспоминания, анкеты, списки научных работ и опубликованных заметок, некролог). Большой блок документов посвящен общественной и служебной деятельности П.В. Иванова. Заслуженный учитель Карельской АССР бережно сохранял в своем личном архиве отчеты о педагогической и научной деятельности, сообщения о педагогических съездах и обществах РСФСР, программы совещаний и семинаров по вопросам народного образования, и школьного краеведения, пригласительные билеты и мандаты. Имя профессора П.В. Иванова как ведущего специалиста в стране по школьному краеведению и экологическому воспитанию молодежи было известно в науке. Он активно сотрудничал с Академией педагогических наук СССР, 30 лет был членом президиума республиканского совета педагогического общества РСФСР. Такая деятельность не могла не отразиться в составе фонда, где отложились материалы научно-педагогических советов при президиуме Академии педагогических наук СССР и Министерства высшего и среднего специального образования, программы научно-методических и научно-практических конференций.

Посвятив свою жизнь, главным образом, научнопедагогической деятельности П.В. Иванов, собрал архив рукописей диссертаций, авторефератов, проспектов книг и сборников, пособий для учителей, студентов и аспирантов. Вопросам воспитания и обучения учащихся, развитию школьного краеведения посвящена серия его очерков и статей.

Сохранились в архиве тексты его лекций, выступлений по вопросам педагогики, воспитания и обучения школьников, школьного краеведения, о педагогической деятельности А.Н. Радищева, А.С. Макаренко, о мировом значении русской и советской науки. На протяжении всей своей жизни П.В. Иванов вел активную переписку с научно-образовательными учреждениями (Софийский университет), редакциями газет и журналов, корреспондентами, политиками (Н.В. Подгорный, М.С. Горбачев), учеными и педагогами (среди них - Д.С. Лихачев, М.Н. Скаткин, И.Д. Зверев), студентами [6].

Воспоминания об участии в 200-летнем юбилее Академии наук были в свое время подготовлены П.В. Ивановым для Солигаличского музея, однако данных об их издании обнаружить не удалось.

Воспоминания П.В. Иванова, кроме наблюдений и интересных зарисовок об участниках торжества, содержат также личные эмоции школьника, оказавшегося в среде крупных ученых, руководителей советской науки. Эти эмоции отразились в повторяющейся мысли автора о «внимании и ласке большой науки», проявленной к скромному посланцу юных краеведов Костромской области.

Тематически записки П.В. Иванова можно разделить на три части: предыстория поездки на юбилей, торжественные мероприятия в Ленинграде, осмысление произошедшего после возвращения в г. Солигалич.

Участию в академическом празднике П.В. Иванов был полностью обязан краеведческому движению, получившему небывалое развитие в «золотое десятилетие» 1920-х гг. - время тесной связи «большой науки» и краеведческого движения, содействия в укреплении этой связи академиков С.Ф. Ольденбурга, А.Е. Ферсмана, Н.Я. Марра, С.Ф. Платонова и др. В этот период повсеместно один за другим возникают краеведческие общества, организуются кружки, создаются краеведческие музеи, начинается издание специальных журналов («Краеведение», «Известия Бюро Краеведения», «Экскурсионное дело» и др.), проходят первые Всероссийские и Всесоюзные краеведческие конференции.

В эти послереволюционные годы сотни учащихся 6-10 классов г. Солигалича занимались натуралистической, краеведческой и агитационной (пропаганда научных знаний) работой под руководством страстных краеведов Л.М. Белоруссова, В.Н. Розепина, Н.К. Мовилло. Юные исследователи изучали экономику деревни, местную флору и фауну, полезные ископаемые, фольклор, вели метеорологические, фенологические и гидрометеорологические наблюдения. В этой работе помогали установленные связи с центральным бюро краеведения в Ленинграде и центральной станцией юных натуралистов им. К.А. Тимирязева в Москве.

По представлению Правления Солигаличского краеведческого общества девятнадцатилетнего П.В. Иванова - председателя одного из крупных и активных объединений школьников краеведов и натуралистов Костромского края - Центральное бюро краеведения направило для участия в торжествах Академии. В Ленинграде на приеме у академика А.Е. Ферсмана П.В. Иванов рассказал о работе краеведов и представил «Адрес» (тетрадь с приветствиями Академии, описание краеведческих исследований, фотографии) для вручения Академии во время торжества. Тогда же П.В. Иванов получил официальное приглашение на юбилейные мероприятия (5-15 сентября 1925 г.). В архивном фонде сохранилась фотокопия пригласительного билета Российской академии наук на имя Павла Владимировича Иванова, подписанного секретарем академиком А.Е. Ферсманом.

Новые впечатления юного краеведа ожидали на следующий день, когда А.Е. Ферсман представлял его президенту Академии А.П. Карпинскому, вицепрезиденту В.А. Стеклову и непременному секретарю С.Ф. Ольденбургу. Короткий разговор о краеведении, о надеждах зрелых ученых на юных изыскателей завершился общей фотографией и вручением «Адреса» солигаличских юннатов-краеведов.

В воспоминания П.В. Иванова, написанные в 1967 г., вставлены фрагменты статей сентябрьских номеров ленинградской газеты «Смена» за 1925 г. с описанием курьезных случаев: приход в канцелярию Академии во время юбилейных торжеств крестьянина, чтобы вручить ученым послание от своих односельчан; присланное приветствие от пожарных Курской губернии («Мы всей командой стоим за то, чтобы русская наука процветала на многие века, побивая при этом буржуазные науки») с просьбой к ученым сделать «мазь от козьего духу». Российская деревня ожидала, что Академия окажет реальную помощь в механизации сельского труда, переустройстве экономики и культуры деревни. 
Бровина А.А., Егорова С.Л.

Торжества продолжались 6 дней. Участники юбилея, среди них и П.В. Иванов, посетили зоологический и геологический музеи Академии, Пушкинский дом, лабораторию академика П.И. Павлова, Зимний дворец, Ботанический сад, Исаакиевский собор, университет, парки и дворцы Петергофа, стали зрителями спектаклей Мариинского театра «Руслан и Людмила», «Князь Игорь».

На торжественных заседаниях, экскурсиях, спектаклях юный краевед Иванов встречал М.И. Калинина, А.В. Луначарского, Г.М. Кржижановского, М.Н. Тухачевского. Незабываемым остался эпизод встречи с К.Е. Ворошиловым в театре во время антракта: «... Я неожиданно встретил К.Е. Ворошилова, возвращавшегося из зала. Он взглянул на меня и спросил: "Нy, молодой человек, видели ли вы своего наркома?" (он имел в виду Луначарского). Увидев легендарного командарма, я так растерялся, что ничего не смог сказать, и он быстро добавил: "Идите скорее в фойе, он там студентам автографы дает". Я бросился в фойе, но... прозвенел последний звонок, и я увидел уходящего А.В. Луначарского, окруженного толпой молодежи и гостей» $[6$, л. 9]. Не забудет Павел Иванов и многих ученых, которых увидел впервые на юбилее Академии: А.П. Карпинского, А.В. Стеклова, А.Е. Ферсмана, А.Ф. Иоффе, С.Ф. Платонова и др.

Упомянем здесь и иные воспоминания об академическом юбилее - заметки зрелого ученого-микробиолога, арктического исследователя Б.Л. Исаченко (1871-1948 гг.). Заметки представляют собой машинописный текст на двух листах, составленный в 1925 г. Б.Л. Исаченко описывает праздник науки как прекрасно организованное масштабное мероприятие большого общественного значения. Автор называет имена зарубежных ученых, прибывших на юбилей «после годов отчуждения и блокады, когда связь с научными центрами Европы была надолго порвана», европейских и отечественных делегатов-микробиологов. Упоминаются темы выступлений секретаря С.Ф. Ольденбурга и академика П.В. Лазарева на двух (6 и 11 сентября) торжественных собраниях Академии. Заметки Б.Л. Исаченко, таким образом, дают краткий информационный материал об участниках юбилея и значении этого события [8, л. 1-2]. Здесь мы не отыщем следов личного эмоционального впечатления о событии, мгновенные зарисовки увиденного, создающие у читателя эффект присутствия всё то, что обнаруживаем в воспоминаниях молодого краеведа П.В. Иванова, впервые оказавшегося на всесоюзном празднике науки.

Поездка П.В. Иванова в Ленинград и рассказы о юбилее Академии своим землякам служили, по словам автора воспоминаний, убедительным доказательством тому, «что отныне двери науки доступны, открыты для всех нас, что сбылись слова великого ученого К.А. Тимирязева о единстве науки и демократии, что наше дело овладеть наукой, учиться применять ее в строительстве новой жизни» [6, л. 11].

Позднее, в годы своего учительства и многолетнего руководства кружками юных краеведов, П.В. Иванов будет часто рассказывать ученикам о 200-летнем юбилее Академии, вспоминая сказанное ему в 1925 г. А.П. Карпинским: «... Любите науку... Изучайте свой край» [6, л. 3].
К этому времени краеведение прочно вошло в инструментарий советской педагогики, став не только областью внеклассной работы, но и элементом обучения. Это направление в свое время горячо поддерживали А.В. Луначарский, Н.К. Крупская. В 1926 г. было принято решение VI пленума Центрального бюро краеведения о разработке «основных начал краеведения как науки». Но ликвидация в середине 1930-х гг. краеведческих органов в центре и на местах надолго прервала эту работу [9, с. 11].

Пережив годы репрессивной политики, разгрома краеведческих обществ, изъятия из обращения краеведческой литературы, краеведение вновь активизировалось в послевоенные годы. В возрождении школьного краеведения сыграло свою роль создание Академии педагогических наук РСФСР (1943 г.), в рамках которой были образованы комиссия и кабинет по школьному краеведению. В 1940-е - 1950-е гг. АПН выпустила ряд сборников, где освещался передовой опыт учителей краеведения. Еще более укрепил положение школьного краеведения Закон СССР «Об укреплении связи школы с жизнью и о дальнейшем развитии системы народного образования в СССР» (24 декабря 1958 г.).

Со временем краеведение стало, по мысли академика Д.С. Лихачева, «самым массовым видом науки», вобравшим в себя научную, культурно-просветительскую, памятнико-охранительную, общественную деятельность. Краеведческие представления, лежащие в основе формирования научных знаний и общих понятий об обществе, природе, взаимосвязи времен, вылились в оформление исторического, географического, литературного, религиозного краеведения и такого специализированного направления как школьное краеведение» [10]. Значительную роль в этом сыграли неравнодушные педагоги, краеведыэнтузиасты, трудившиеся в городах и сельской глубинке.

Свое представление о роли краеведения в общеобразовательной и трудовой подготовке учащихся, их нравственном, эстетическом воспитании, об особенностях краеведческой работы учителя П.В. Иванов представил в своей работе «Педагогические основы школьного краеведения» (Петрозаводск, 1966 г.), включив сюда конкретные предложения по развитию системы советского школьного краеведения и проект программы по «Основам школьного краеведения». В 1968 г. он защитил докторскую диссертацию «Краеведение в системе учебной и внешкольной работы средней общеобразовательной школы».

П.В. Иванов, пройдя путь от ученика сельской школы, увлеченного краеведением, до школьного учителя, а затем и профессора университета, закладывал в своих студентах - будущих учителях мысль о необходимости воспитывать у учащихся интерес, любовь и стремление к юннатской, краеведческой, научно-изыскательской работе. Участие в юбилейных торжествах главного научного центра Советской России в 1925 г. стало ключевым событием в жизни профессора П.В. Иванова, отразившего это в своих воспоминаниях одной лишь фразой: «...Я унес с юбилея Академии неугасимую искру любви к науке...». 


\section{Список литературы:}

1. Известия Российской академии наук. VI серия. Петроград, 1918. № 14. С. 1387-1399.

2. «Мы не нищие...»: к истории 200-летнего юбилея Российской Академии наук (из дневника Е.Г. Ольденбурга) / Публ. М.Ю. Сорокиной // Источник. 1999. № 6. С. 28-41.

3. Черказьянова И.В. Юбилеи Академии наук как фактор развития историографии в советский и современный период / Институт истории естествознания и техники им. С.И. Вавилова. Годичная конференция, 2009. М.: Анонс Медиа, 2009. С. 660-662.

4. Собрание узаконений и распоряжений Рабочего и Крестьянского правительства РСФСР. 1925. № 48. Ст. 363.

5. Молас Б.Н. Юбилейные дни // Научный работник. 1925. № 3. С. 43-47.
6. Национальный архив Республики Карелия.

Ф. Р-131. Оп. 1. Д. 57. Л. 1-12.

7. Карелия: энциклопедия: в 3 т. / гл. ред. А.Ф. Титов. Т. 1: А-Й. Петрозаводск: ИД «ПетроПресс», 2007. С. 361-362.

8. Исаченко Б.Л. Заметки о 200-летнем юбилее Академии наук Союза ССР 1725-1925. Машинопись // Архив РАН. Ф. 583. Оп. 1. Д. 9. Л. 1-2.

9. Иванов П.В. Педагогические основы школьного краеведения. Петрозаводск, 1966. 181 с.

10. Интервью С.О. Шмидта: «Речь идет о сохранении России» // Наше наследие. 2005. № 74.

Публикация подготовлена при поддержке Комплексной программы УрО РАН «Исследователи Севера России: биографика и научное наследие» (проект 18-6-6-2).

\title{
«...INEXTINGUISHABLE SPARK OF LOVE FOR SCIENCE APPEARED IN ME DURING THE ANNIVERSARY OF THE ACADEMY...» (THE MEMORIES OF P.V. IVANOV - YOUNG PARTICIPANT OF THE 200TH ANNIVERSARY OF THE RUSSIAN ACADEMY OF SCIENCES)
} (C) 2018

\author{
Brovina Alexandra Alexandrovna, candidate of historical sciences, \\ head of Humanities Interdisciplinary Studies Department \\ Egorova Svetlana Lvovna, candidate of historical sciences, \\ senior researcher of Humanities Interdisciplinary Studies Department \\ Komi Scientific Center of Ural Branch of Russian Academy of Sciences (Syktyvkar, Russian Federation)
}

Abstract. The paper is devoted to one of the iconic pages in the history of academic science - the $200^{\text {th }}$ anniversary of the USSR Academy of Sciences. A broad program of the «science holiday» on an international scale with the invitation of foreign scientists, pointed to the scientific and political significance of the event, both to raise the prestige of the Academy of Sciences, and to demonstrate to the international community the loyalty of the scientific elite to the new government. Researchers repeatedly turned to the analysis of this event and stressed its importance. However, on the eve of the next anniversary, it is interesting to show this event from an unofficial position, attracting sources of personal origin. The paper focuses on the unpublished memoirs of Pavel Vladimirovich Ivanov (19061990), scientist-teacher, doctor of pedagogical sciences, professor, honored teacher of the Karelian ASSR. In 1925 he as a young local historian from the city of Soligalich of the Kostroma province became a participant of the academic celebrations. The impressions of this event predetermined his future destiny and choice of profession. P.V. Ivanov having traveled from a pupil of a rural school, keen on local lore studies, to a schoolteacher, and then a university professor, laid down in his students - future teachers - the idea to raise the pupils' interest, love and desire for young naturalists', local lore, scientific and research work.

Keywords: history of Russian Academy of Sciences; jubilee celebrations; collective memory; unpublished memories; scientist-teacher; professor Pavel Vladimirovich Ivanov; local lore, scientific and research work; education of students; Soligalich of Kostroma province; National Archive of Republic of Karelia.

УДК 94(47).084.3+94(47).084.5

Статья поступила в редакцию 05.01.2018

\section{ФОРМИРОВАНИЕ НОВОГО БЫТА МОЛОДЕЖИ В 1920-Е ГОДЫ}

(C) 2018

\author{
Шмелёв Сергей Анатольевич, научный сотрудник музея авиации и космонавтики \\ Самарский наџиональный исследовательский университет имени академика С.П. Королёва
} (2. Самара, Российская Федераџия)

\footnotetext{
Аннотация. В данной статье рассматривается проблема формирования нового быта молодежи в 1920-е гг., имевшая большое значение в работе партии большевиков по коммунистическому воспитанию молодого поколения. Формирование нового быта молодежи имело свои особенности и было направлено на преодоление традиционных форм индивидуалистического быта, воспитание коммунистического мировоззрения, развитие коллективных форм взаимоотношений среди подрастающего поколения, вовлечение молодежи в борьбу с религиозными и другими бытовыми пережитками. Партия стремилась установить контроль и руководить молодежью через комсомольские организации. В работе комсомола отразились все противоречия, присущие переходной эпохе 1920-х годов. В статье на конкретных фактах раскрыты основные формы и методы практической работы по формированию нового быта среди молодежи, направленные на изменение повседневных отношений между юношами и девушками; постановку массовой работы в молодежной среде через клубы, спортивные и танцевальные кружки, кинематограф; мобилизацию молодых людей на борьбу с быто-
} 